\title{
About This Book
}

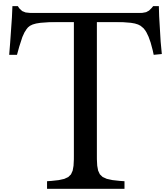

he repudiation of Russia's debt by the Bolsheviks affected French investors for several generations. The reason for this was the sheer volume of money lent by institutional investors and private citizens alike. Although estimates of the precise amounts lent to the Russian empire vary, there is general agreement about their size relative to the French economy-approximately 4.5 percent of national wealth at the time.

Despite the huge amounts involved, few economists have attempted to analyze this extreme example of debt repudiation. René Girault's seminal book (1973) offers a fascinating and meticulous account of the appearance of Russian bonds in French investors' portfolios. But the scope of that study is limited to the period from 1887 to 1914 and therefore does not address the repudiation and its consequences. Several more recent books appeared when negotiations with Russia were reopened. However, these seek to express a position on repayment, analyze the legal aspects of the repudiation, or denounce the "scandalous spoliation."

This book analyzes the repudiation from the angle of modern financial theories. It concentrates on sovereign debt issued by the former tsarist empire and therefore excludes bonds issued by private companies. The first section describes the development of sovereign default and re- 
pudiation theory, before examining the case of Russian debt repudiation. The analysis rests largely on a phenomenon of some significance: counterintuitively, market prices for Russian debt remained remarkably high, both in absolute and relative terms, for several years after the repudiation. Far from being a sign of irrational behavior, this trend can be attributed to expectations that one or more extreme events could occur. The subsequent sections of this book analyze these expectations. Each chapter considers the historical and financial factors that encouraged French investors to hope their bonds would be redeemed. The final chapter presents the econometric and financial analyses performed on the Russian data to determine the relative importance, in quantitative terms, of each of these reasons for hope. 